\title{
Some Considerations on Silicone Oil in High-Current and Energy-Disconnecting Mechanisms
}

LA- - $10035-115$

Herbert F. Vogel

DE84 011021

\section{DISCLAIMER}

\begin{abstract}
This report was prepared as an account of work sponsored by an agency of the United States Government. Neither the United States Government nor any agency thereof, ner any of their employees, makes any warranty, express or implied, or assumes any legal liability or responsibility for the accuracy, completeness, or usefulness of any information, apparatus, product, or process disclosed, or represents that its use would not infringe privately uwned rights. Reference herein to any specific commercial product, process, or service by trade name, trademark, manufacturer, or otherwise does not necessarily constitute or imply its endorsement, recommendation, or favoring by the United States Government or any agency thereof. The views and opinions of authors expressed herein do not necessarily state or reflect those of the United States Government or any agency thereof.
\end{abstract}

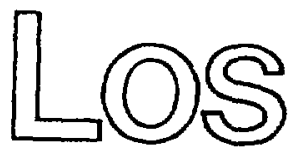


SOME CONSIDERATIONS ON SILICONE OIL

IN HIGH-CURRENT AND ENERGY-DISCONNECTING MECHANISMS

by

Herbert F. Voge1

\begin{abstract}
Silicone oil is considered inflammable. The dissociation products generated by an electric arc under silicone oil are known to form a highly explosive mixture with air. We calculate the arc energy required for dissociation to be $32 \mathrm{~kJ}$ per liter of gas mixture at standard pressure and temperature. We calculate the arc voltage gradient at a pressure of 50 atm and current density of $1 \mathrm{kA} / \mathrm{mm}^{2}$ to be $0.5 \mathrm{kV} / \mathrm{cm}$, resulting in an arc voltage of several kV, depending on the arc length. In a multikiloampere arc, the resulting arc power is likely to cause a pressure of many atmospheres in a shock wave.
\end{abstract}

\title{
I. INTRODUCTION
}

In the coil protection circuit for the Large Coil Project (LCP) and in the plans of the former $2 \dot{0}-\mathrm{MJ}$ project of the Tokamak Poloidal Field systems (TPFS), a dc current interrupter is used, consisting of a contactor for continuous duty in shunt with a fast circuit breaker. The contactor is a mechanical device designed to carry continuous current between contacts made by an obtuse wedge with rounded edges inserted, by an eccentric rotation, between the two bus sections. The open contacts are designed to withstand open circuit voltages of $0.6 \mathrm{kV}$ in air. To obtain the desired dielectric strength between open contacts, the contactor, when modified, may be submerged in a box filled with approximately $24 \mathrm{~kg}$ of silicone fluid, to withstand $80 \mathrm{kV}$.

To discuss the hazard potential associated with the silicone fluid is our objective, in view of the large amount of energy stored in the coils. The stored energy is 100 to $200 \mathrm{MJ}$ in each LCP circuit and $20 \mathrm{MJ}$ in the TPFS. A significant part of that energy may transfer into the arc when the contacts 
are accidentally opened while the parallel connected breaker is open. The flash point of the silicone fluid is $320^{\circ} \mathrm{C}$. Under the effects of an electric arc, however, the fluid may become dissociated, which results in a mixture of gases highly explosive in contact with air or oxygen when the bath is not covered with inert atmosphere and properly vented. The rate of gas generation and some secondary phenomena are discussed.

\section{THE DISSOCIATING REACTION}

Silicone fluids are inorganic compounds of the dimethylsiloxane type

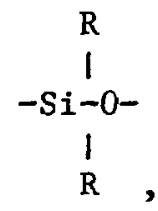

where the radical $\mathrm{R}$ in the present case is $\mathrm{CH}_{3}$. The composition ${ }^{l}$ of the dissociated gas products is shown in Table $I$. The gas evolution rate shown in Fig. 54 of Ref. 1 is given as a charge transfer function over a small range, which cannot readily be extrapolated. A linear silicone compound and its dissociating reaction whose stoichiometric composition is comparable with that in Table I are given by

$$
\left[\left(\mathrm{CH}_{3}\right)_{2} \mathrm{Si} 0\right]_{5}+\mathrm{q}+\mathrm{Si}_{5}+2 \mathrm{CH}_{4}+2 \mathrm{C}_{2} \mathrm{H}_{2}+3 \mathrm{CO}+\mathrm{CO}_{2}+9 \mathrm{H}_{2} \text {, }
$$

where the endothermic energy $q$ is to be deter ined. We chose 5 as the end-to-end chain length, because the calculated rms value of 4.92 has been reported ${ }^{2}$ with an observed length of 7.3 . The following bonding energies may be assumed: ${ }^{3,4} \mathrm{H}-\mathrm{H}, 4.6 \mathrm{eV} ; \mathrm{C}-\mathrm{C}, 3.5 \mathrm{eV} ; \mathrm{C}-\mathrm{Si}, 3.2 \mathrm{eV} ; \mathrm{Si}-0,3.2 \mathrm{eV}$; C-H, $4.3 \mathrm{eV} ; \mathrm{Si}-\mathrm{Si}, 2.3 \mathrm{eV} ; \mathrm{C}=0,-1.4 \mathrm{eV} ; \mathrm{C}=0_{2},-2.8 \mathrm{eV} ; \mathrm{C}=\mathrm{C}, 0.6 \mathrm{eV}$. Hence, the sum of the bond potentials on the l.h.s. is $203 \mathrm{eV}$, that on the r.h.s. is $75 \mathrm{eV}$, and $\mathrm{q}=203-75 \simeq 129 \mathrm{eV}$. For the $18 \mathrm{~mol}$ of gases on the r.h.s. of the reaction, the energy $q$ may be expressed as $32.4 \mathrm{~kJ}$ per liter of total gas volume at standard pressure and temperature, which is $12.4 \mathrm{MJ} / \mathrm{g}-\mathrm{mole}$ of the silicone compound. Because the latent heat of vaporization is given (Ref. 2, p. 514) as $19.7+6.91 .5(\mathrm{~kJ} / \mathrm{g}-\mathrm{mole})$ and the specific heat ${ }^{5}$ as $1.47 \mathrm{~J} / \mathrm{g}$, the minimum equilibrium temperature for the fully dissociated gas mixture follows from the $12.4 \mathrm{MJ} / \mathrm{g}$-mole bonding energy to be $22.8 \mathrm{kl}$. The arc temperature may be at least that much. The ionization is discussed in Sec. III. 
TABLE I

COMPOSITION OF THE GASEOUS MIXTURE FORMED FROM

SILICONE LIQUID ( $1 \mathrm{~cm}^{2} / \mathrm{s}$ kinematic viscosity)

Percentage of Total

$\frac{\text { Gas }}{\mathrm{H}_{2}}$

Gas Volume, wh

$\mathrm{CH}_{4}$

78.1

CO

9.7

$\mathrm{C}_{2} \mathrm{H}_{2}$

5.7

$\mathrm{C}_{2} \mathrm{H}_{4}$

3.5

$\mathrm{C}_{2} \mathrm{H}_{6}$

2.0

$\mathrm{CO}_{2}$

0.9

0.1

\section{IONIZATION AND ARC PROPERTIES}

The statistically dominant ionized species with their ionization potential and electronic collision probability $P_{c}$ are listed in Table II, where the potentials are from Ref. 3 and the $P_{c}$ values from Brown. ${ }^{6}$ Because the relatively low equilibrium temperature implies an ionized gas, not a plasma, the ionization is sma11, and we may approximate the mixture by treating each species separately and by taking the average in the end. Thus, we have a three-component gas in each case, consisting of electrons, ions, and neutrals. The equilibrium relationship for a three-component gas is given ${ }^{7}$ by

$$
\begin{aligned}
& \left(\frac{n}{n_{o}}\right)^{\tau_{0}}\left(\frac{p^{o}}{1+\tau_{i}+\tau_{o} \frac{n_{o}}{n}}\right)^{1+\tau_{i}-\tau_{o}} \\
= & \left.g\left(\frac{2 \pi}{h^{2}}\right)^{\frac{3}{2}\left(1+\tau_{i}-\tau_{o}\right.}\right)\left(\frac{m_{e} m_{i}}{m_{o} \tau_{o}}\right)^{\frac{3}{2}} e^{-\left(E_{i} / k T_{e}\right)} \cdot \frac{\left(k T_{i}\right)^{\frac{3}{2} \tau_{i}}}{\left(k T_{o}\right)^{1.5 \tau_{o}}}\left(k T_{e}\right)^{\frac{5}{2}+\tau_{i}-\tau_{n},},
\end{aligned}
$$

where the subscripts $e, i$, and $o$ denote the respective species; the number density $n_{e}=n_{i}$ is denoted $n ; p^{0}$ is the total pressure, which is invariant in the reaction; and $g$. is the statistical weight for which we use the numbers 
given in the Appendix. both temperature ratios, $\tau_{i} \equiv T_{i} / T_{e}$ and $\tau_{0} \equiv T_{0} / T_{0}$, equal 1 , the ionized gas resting in isothermal equilibrium.

TABLE II

IONIZING REACTIONS AND PROPERTIES

\begin{tabular}{|l|c|}
\hline Reaction & $\begin{array}{c}\text { Electron - neutrals } \\
\text { collision probability } \mathrm{P}_{\mathrm{c}} \text { at } 2 \mathrm{eV} \\
\left(\mathrm{cm}^{2} / \mathrm{cm}^{3} \text { torr }\right)\end{array}$ \\
\hline $\mathrm{H}_{2} \rightarrow \mathrm{H}_{2}^{+}+\mathrm{e}-15.4 \mathrm{eV}$ & 48 \\
$\mathrm{CH}_{4} \rightarrow \mathrm{CH}_{4}^{+}+\mathrm{e}-12.7 \mathrm{eV}$ & 15 \\
$\mathrm{CO}+\mathrm{CO}^{+}+\mathrm{e}-14.0 \mathrm{eV}$ & 60 \\
$\mathrm{C}_{2} \mathrm{H}_{2} \rightarrow \mathrm{C}_{2} \mathrm{H}_{2}^{+}+\mathrm{e}-11.4 \mathrm{eV}$ & 70 \\
$\mathrm{C}_{2} \mathrm{H}_{4} \rightarrow \mathrm{C}_{2} \mathrm{H}_{4}^{+}+\mathrm{e}-10.5 \mathrm{eV}$ & \\
$\mathrm{C}_{2} \mathrm{H}_{6} \rightarrow \mathrm{C}_{2} \mathrm{H}_{6}^{+}+\mathrm{e}-10.6 \mathrm{eV}$ & \\
$\mathrm{CO}_{2} \rightarrow \mathrm{CO}_{2}^{+}+\mathrm{e}-13.8 \mathrm{eV}$ & \\
\hline
\end{tabular}

The first question concerns the unknown total pressure. Evidently, when the arc voltage is small, energy transfers from the external circuit at a slow rate and the pressure equals that above the fluid, that is, 1 atm. Such a relatively low pressure would imply a current density of less than the observed $100 \mathrm{kA} / \mathrm{cm}^{2}$. Shock waves with many atmospheres have been reported, 8 however. That observation is plausible because $0.2 \mathrm{~ms}$ is approximately the time a sonic wave takes from the arc to the fluid surface and back. The arc power per unit arc length is $3 \mathrm{MW} / \mathrm{cm}$, as discussed near the end of this report, yielding $W=6 \mathrm{~kJ} / \mathrm{cm}$ of energy in a $0.2-\mathrm{ms}$ time interval. A spherical gas bubble with diameter equal to the arc length may thus be expected to expand behind a spherical shock front driven by a pressure that is initialiy, i.e., at $t=0.2 \mathrm{~ms}$,

$$
\frac{W}{40} \quad \frac{3 \pi}{a^{3}}
$$

under the effect of gas generation at $\frac{1}{40} \mathrm{l} / \mathrm{kJ}$, at standard temperature and pressure (STP), when $2 a$ is the arc length. With $2 a=1 \mathrm{~cm}$, the pressure is thus 160 atmospheres. The observed energy transfer rate in the arc is large, 
and the arc voltage amounts to a few $\mathrm{kV}$. The average pressure in the observed shock wave under ofl is $50 \mathrm{~atm}$, approximately. Therefore, we evaluate Eq.(2) for $\mathrm{p}^{\circ}=50 \mathrm{~W}_{\gamma} \mathrm{T} / 273.16$. The resulting ionization $\mathrm{X}$ is listed in Table III for the two assumed temperatures, $T=22 \mathrm{kK}$ and $24 \mathrm{kK}$. The average ionization potential, as determined from the weights $w_{\gamma}$ in Table $I$ and $E_{i}$ in Table III, is $13.4 \mathrm{eV}$ with an average degree of ionization $\overline{\mathrm{X}}=0.102$ at $22 \mathrm{kK}$ or $\overline{\mathrm{X}}=0.160$ at $24 \mathrm{kK}$. The energy required for the fractional ionization of the 17 mol on the r.h.s. in Reaction (1) may thus be estimated to be $17 \cdot 13.4 \cdot(0.102$ or 0.160$)=23.2$ or $36.4 \mathrm{eV}$, that is, approximately $29.8 \mathrm{eV}$ at $23 \mathrm{kK}$, corresponding to $2.9 \mathrm{MJ} / \mathrm{g}-\mathrm{mole}(7.4 \mathrm{~kJ}$ per STP liter of gas mixture). Thus, we estimate $32.4+7.4=40 \mathrm{~kJ}$ to be spent per STP 1iter of the gas mixture.

To estimate the rate of gas generation, one needs the arc voltage. Schaper (Ref. 8, p. 67, p. 83, and Fig. 35) reported experimental work with arcs under transformer oil. He observed voltage gradients of 30 to $60 \mathrm{kV} / \mathrm{m}$ with the arc voltage not exceeding $6 \mathrm{kV}$ in an arc-induced pressure pulse. The reported ${ }^{8}$ peak is $88 \mathrm{~atm}$, corresponding to an average pressure $\mathrm{p}^{0}=50 \mathrm{~atm}$, used as pressure basis in our calculations. The arc current density is reported (Ref. 8, p. 7, and Ref. 9) not to exceed $100 \mathrm{kA} / \mathrm{cm}^{2}$ under transformer oil. For the device of particular interest in the present study, we assume $\mathrm{J}=100 \mathrm{kA} / \mathrm{cm}^{2}$. Because a close estimate of the arc envelope can be made by minimizing the Lagrangean function of a noncollisional electron model, independency of the choice of fluid may be expected concerning $J$ (Ref.7, pp. 43-48). Hence, the voltage gradient is determined for the given $\mathrm{J}$ and $\mathrm{p}^{\mathrm{o}}$ as follows.

The drift velocity is given from elementary considerations; that is,

$$
\mathrm{v}_{\mathrm{d}}=\mathrm{Ed} \lambda / \mathrm{m} \overline{\mathrm{v}}
$$

where $\lambda$ is the mean free path (m.f.p.) in elastic electron-atom collisions and $\lambda \equiv \lambda_{\text {eo }}$ as calculated from the collision probability $P_{c}$. Table III shows $P_{c}$ and $\lambda_{\text {eo }}$ for each of the predominant species. From Eq. (3) follows the current density in an ionized gas, 
TABLE III

ELASTIC COLLISION PROPERTIES OF THE PREDOMINANT IONIZED SPECIES AT THE ASSUMED CURRENT DENSITY $J=100 \mathrm{kA} / \mathrm{cm}^{2}$ AND TOTAL PRESSURE $\mathrm{p}^{\circ} \approx 50 \mathrm{~atm}$ FOR ISOTHERMAL EQUILIBRIUM AT $22 \mathrm{kK}$ or $24 \mathrm{kK}$

\begin{tabular}{|c|c|c|c|c|c|c|c|c|c|}
\hline \multirow{2}{*}{$\begin{array}{l}\text { Species } \\
\gamma\end{array}$} & \multirow{2}{*}{$\begin{array}{l}\text { Tem- } \\
\text { pera- } \\
\text { ture } \\
\mathrm{T} \\
\\
\mathrm{kK}\end{array}$} & \multirow{2}{*}{$\begin{array}{l}{ }^{E_{\lambda}} \\
\\
e V\end{array}$} & \multirow{2}{*}{$\begin{array}{l}{ }^{{ }^{P}} c_{\lambda} \\
*\end{array}$} & \multicolumn{2}{|c|}{$\begin{array}{c}\text { Electronic } \\
\text { Mean Free } \\
\text { path }\end{array}$} & \multirow{2}{*}{$\begin{array}{l}\text { Frac- } \\
\text { tional } \\
\text { ioni- } \\
\text { zation } \\
\quad X\end{array}$} & \multicolumn{2}{|c|}{$\begin{array}{l}\text { Voltage gradient } \\
\text { from the elastic } \\
\text { collisions }\end{array}$} & \multirow{2}{*}{$\begin{array}{l}E_{\lambda}= \\
E_{e o}+E_{e i} \\
\mathrm{kV} / \mathrm{m}\end{array}$} \\
\hline & & & & $\lambda_{\text {eo }}$ & $\lambda_{\mathrm{ei}}$ & & $\begin{array}{l}\text { elec- } \\
\text { tron } \\
\text { Neu- } \\
\text { trals } \\
\mathrm{E}_{\mathrm{eg}} \\
\mathrm{kV} / \mathrm{m}\end{array}$ & $\begin{array}{l}\text { elec- } \\
\text { tron } \\
\text { ions } \\
\quad E_{e j} \\
\quad \mathrm{kV} / \mathrm{m}\end{array}$ & \\
\hline $\mathrm{H}_{2}^{+}$ & $\begin{array}{l}22 \\
24 \\
\end{array}$ & 15.4 & 48 & $\begin{array}{l}51.9 \\
56.6 \\
\end{array}$ & 104 & $\begin{array}{l}0.0950 \\
0.142\end{array}$ & $\begin{array}{l}53.1 \\
38.7\end{array}$ & $\begin{array}{l}26.0 \\
22.2\end{array}$ & $\begin{array}{l}136 \\
97.0\end{array}$ \\
\hline $\mathrm{CH}_{4}^{+}$ & $\begin{array}{l}22 \\
24\end{array}$ & 12.7 & 15 & $\begin{array}{l}166 \\
181\end{array}$ & $\begin{array}{l}132 \\
118\end{array}$ & $\begin{array}{l}0.484 \\
0.615\end{array}$ & $\begin{array}{l}20.6 \\
14.6\end{array}$ & $\begin{array}{l}28.2 \\
24.4\end{array}$ & $\begin{array}{l}262 \\
218\end{array}$ \\
\hline $\mathrm{Co}^{+}$ & $\begin{array}{r}22 \\
24 \\
\end{array}$ & 14.0 & $\begin{array}{l}60 \\
60 \\
\end{array}$ & $\begin{array}{r}41.5 \\
45.3 \\
\end{array}$ & $\begin{array}{l}124 \\
112 \\
\end{array}$ & $\begin{array}{l}0.455 \\
0.597 \\
\end{array}$ & $\begin{array}{l}74.9 \\
53.7 \\
\end{array}$ & $\begin{array}{r}27.2 \\
23.6 \\
\end{array}$ & $\begin{array}{l}439 \\
357 \\
\end{array}$ \\
\hline $\mathrm{C}_{2} \mathrm{H}_{2}$ & 24 & 11.4 & $\begin{array}{l}70 \\
70 \\
\end{array}$ & $\begin{array}{r}35.6 \\
38.8 \\
\end{array}$ & $\begin{array}{l}87.8 \\
83.0\end{array}$ & $\begin{array}{l}0.878 \\
0.929\end{array}$ & $\begin{array}{l}48.7 \\
37.8\end{array}$ & $\begin{array}{l}21.4 \\
19.2\end{array}$ & $\begin{array}{l}\frac{371}{476} \\
442\end{array}$ \\
\hline Average ${ }^{*}$ & $*^{22}$ & $\overline{\mathrm{E}}=1$ & {$\left[\overline{E_{\mathrm{eo}}}\right.$} & $\frac{1}{+E_{e 2}}$ & $\frac{1}{E_{e o 2^{+}}}$ & $\sigma_{\mathrm{e} 2}+\cdots$ & & & $\begin{array}{l}57.2 \\
45.4\end{array}$ \\
\hline $\begin{array}{ll}* & \text { Prob } \\
* * & \text { of }\end{array}$ & $\begin{array}{l}\text { abilit } \\
11 \text { spe }\end{array}$ & $\begin{array}{l}y \text { of } \\
\text { cies }\end{array}$ & $\begin{array}{l}11 \text { is } \\
\text { sted }\end{array}$ & $\begin{array}{l}\text { Lon }(\mathrm{c} \\
\text { in } \mathrm{Ta}\end{array}$ & $\begin{array}{l}\text { torr } \\
\text { Les I }\end{array}$ & ${ }^{-1}$ and II. & & & \\
\hline
\end{tabular}

where $\mathrm{n}_{e}$ is the electron number ciensity and $\mathrm{m}_{e}$ the electron mass. Because $J=100 \mathrm{kA} / \mathrm{cm}^{2}$ and $E_{e o}$ is the unknown, $E_{q} .(4)$ is solved for $E_{e o}$, with the results tabulated in Table III. For the Coulomb interactions, we "se the Spitzer resistivity, $n_{s p}$, to obtain

$E_{e i}=\eta_{s p} J$ 
listed in Table III. The corresponding mean free path in the Coulomb collision is listed also. By adding $E_{e o}$ and $E_{e l}$ for each species and averaging over all of them as indicated in Table III, we obtained the mean gradient $\bar{E}=48 \mathrm{kV} / \mathrm{m}$ when the arc temperature is $23 \mathrm{kK}$, the current density $J=100 \mathrm{kA} / \mathrm{cm}^{2}$, and the pressure outside the arc 50 atmospheres. This gradient $\bar{E}$ is within the range observed by Schaper (Ref. 8, p. 67, p. 83, and Fig. 35) under transformer oil. The power in a 25-kA arc thus calrulated is 3 MW per cm arc length.

IV. CONCLUSIONS

Given the separation of the opening contacts, hence the approximate arc length, the arc power may be obtained from our caiculated 45- to 48-kV/m gradient. With $40 \mathrm{~kJ}$ per $\ell$ of ionized gas, at STP, the rate of explosive gas generation may thus be estimated.

\section{ACKNOWLEDGMENT}

This work was done when the Energy Storage Group under J. D. Rogers at Los Alamos tested the 25-kA bypass switches fo: the Large Coil Project at Oak Ridge and we studied theoretical aspects. Robert W. Walker kindly reviewed and contributed some of the quantum statistical degeneracy numbers used in this work. The arc model is based on work done by the author in 1979 at the University of Texas at Austin, when I benefited from the significant advice of W. C. Duesterhoeft, Jr., Lothar Frummhold, E. J. Powers, Jr., R. M. Walser, P. Wildi, and H. H. Woodson. M. Klein was consulted on a numerical method. 
DERIVATION OF THE QUANTUM STATISTICAL WEIGHTS

1. Quantum Statistica1 Degeneracies ${ }^{3}, 10$

$\begin{array}{llll}\text { Species } & \text { Degeneracy } & \text { Species } & \text { Degeneracy } \\ \text { Electron } & \mathrm{g}_{\mathrm{e}}=2 & \mathrm{C}_{2} \mathrm{H}_{4} & \mathrm{gC}_{2} \mathrm{H}_{4}=1 \\ \mathrm{H}_{2} & \mathrm{~g}_{2}=1 & \mathrm{C}_{2} \mathrm{H}_{4}^{+} & \mathrm{g}_{\mathrm{C}_{2} \mathrm{H}_{4}^{+}}=2 \\ \mathrm{H}_{2}^{+} & \mathrm{g}_{\mathrm{H}_{2}^{+}}^{+}=2 & \mathrm{C}_{2} \mathrm{H}_{6} & \mathrm{~g}_{\mathrm{C}_{2} \mathrm{H}_{6}}=1 \\ \mathrm{CH}_{4} & \mathrm{~g}_{\mathrm{CH}_{4}}=1 & \mathrm{C}_{2} \mathrm{H}_{6}^{+} & \mathrm{g}_{\mathrm{C}_{2} \mathrm{H}_{6}^{+}}=2 \\ \mathrm{CH}_{4}^{+} & \mathrm{g}_{\mathrm{CH}_{4}^{+}}^{+}=2 & & \\ \mathrm{CO}^{+} & \mathrm{g}_{\mathrm{CO}}=1 & \mathrm{CO}_{2} & \mathrm{~g}_{\mathrm{CO}_{2}}=1 \\ \mathrm{CO}^{+} & \mathrm{g}_{\mathrm{CO}^{+}}=2 & & \\ \mathrm{C}_{2} \mathrm{H}_{2} & \mathrm{~g}_{\mathrm{C}_{2} \mathrm{H}_{2}}=1 & \mathrm{CO}_{2}^{+} & \mathrm{g}_{\mathrm{CO}_{2}^{+}}=4 \\ \mathrm{C}_{2} \mathrm{H}_{2}^{+} & \mathrm{g}_{\mathrm{C}_{2} \mathrm{H}_{4}^{+}}=4 & & \end{array}$

2. Ionizing Reactions and Statistical Weight
a) $\mathrm{H}_{2} \rightarrow \mathrm{H}_{2}^{+}+\mathrm{e}$
$\mathrm{g}_{\mathrm{a}}=\mathrm{g}_{\mathrm{H}_{2}^{+}} \times \mathrm{g}_{\mathrm{e}} / \mathrm{g}_{\mathrm{H}_{2}}=4$
b) $\mathrm{CH}_{4} \rightarrow \mathrm{CH}_{4}^{+}+\mathrm{e}$
c) $\mathrm{CO} \rightarrow \mathrm{CO}^{+}+\mathrm{e}$
$\mathrm{g}_{\mathrm{b}}=\mathrm{g}_{\mathrm{CH}_{4}^{+}} \times \mathrm{g}_{\mathrm{e}} / \mathrm{G}_{\mathrm{CH}_{4}}=4$
d) $\mathrm{C}_{2} \mathrm{H}_{2} \rightarrow \mathrm{C}_{2} \mathrm{H}_{2}^{+}+\mathrm{e}$
$\mathrm{g}_{\mathrm{c}}=\mathrm{g}_{\mathrm{CO}}+\times \mathrm{g}_{\mathrm{e}} / \mathrm{g}_{\mathrm{CO}}=4$
e) $\mathrm{C}_{2} \mathrm{H}_{4} \rightarrow \mathrm{C}_{2} \mathrm{H}_{2}^{+}+\mathrm{e}$

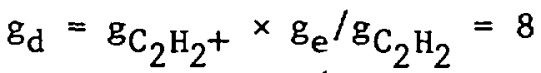
f) $\mathrm{C}_{2} \mathrm{H}_{4}+\mathrm{C}_{2} \mathrm{H}_{6}^{+}+\mathrm{e}$

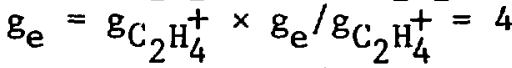
g) $\mathrm{CO}_{2}+\mathrm{CO}_{2}^{+}+\mathrm{e}$

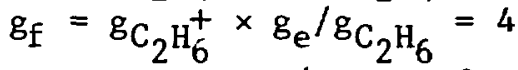
$g_{\mathrm{g}}=\mathrm{g}_{\mathrm{CO}_{2}^{+}} \times \mathrm{g}_{\mathrm{e}} / \mathrm{g}_{\mathrm{CO}_{2}}=8$

REFERENCES

1. Frank M. Clark, Insulating Materials for Design and Engineering Practice (John Wiley and Sons, Inc., New York, 1961), pp. 239-246.

2. Encyclopedia of Polymer Science and Technology (Interscience Publishing, Division of John Wiley and Sons, Inc., New York, 1970), Vol. 12, Table 10 , p. 516.

3. J. L. Franklin, J. G. Dillard, H. M. Rosenstock, J. T. Herron, K. Draxl, and F. H. Field, "Ionization Potentials, Appearance Potentials, and Heats of Formation of Gaseous Positive Ions," National Standard Reference Data Service, National Bureau of Standards document 26 (US Government Printing Office, Washington, DC, June 1969). 
4. International Encyclopedia of Chemical Science, (D. Van Nostrand Co., Inc., 1964), p. 138.

5. F. D. Snell and L. S. Ettree (Editors), Encyclopedia of Industrial Chemical Analysis, (Interscience Publishing, Division of John Wiley and Sons, Inc., 1973), Vol. 18, p. 98.

6. Sanborn C. Brown, Basic Data of Plasma Physics (M.I.T. Press, Cambridge, 1967), Chap. 2 .

7. H. F. Vogel, "Theory of the Arc Discharge in Air Blast Breakers," Los Alamos Scientific Laboratory report LA-8488-T (August 1980), Eqs. (4)-(12), p. 36 .

8. Joachim Schaper, "Über die rasche Erzeugung hoher Lichtbogenspannung an Lichtboegen unter Fluessigkeiten zum Zweck der Kurzschlussbegrenzung in Starkstromanlagen mit Betriebsspannungen unter 1000 Volt," Dissertation (Carolo Wilhelmina Technical Univ., Braunschweig, 1961), Fig. 16 and p. 35 .

9. R. Heizmann, "Abschaltversuche mit verschiedenen Loeschfluessigkeiten und die Zusammensetzung der entstehenden Schaltergase", Dissertation (Swiss Federa1 Inst. of Technol., 1957).

10. C. E. Moore, "Atomic Energy Leve1s," National Bureau of Standards document 467, Vo1. 1 (US Government Printing Office, Washington, DC, 1949). 